TEME, г. ХІІ, бр. 1, јануар - март 2018, стр. 203-223

Прегледни рад

DOI: $10.22190 /$ TEME1801203N

Примљено: 24. 10. 2016.

UDK 351.749:340.134(497.11)

Одобрено за штампу: 12. 3. 2018.

\title{
ПРИВАТНА БЕЗБЕДНОСТ У СРБИЈИ - ПРАВНИ ОСНОВИ И ЕДУКАЦИЈА ПРИПАДНИКА
}

\author{
Жељко Никач ${ }^{1}$, Радован Радовановић ${ }^{1}$, Војкан Зорић ${ }^{2}$ \\ ${ }^{1}$ Криминалистичко-полицијска академија, Београд, Србија \\ ${ }^{2}$ Факултет за цивилно ваздухопловство, Београд, Србија \\ * radovan.radovanovic@kpa.edu.rs
}

\begin{abstract}
Апстракт
Сектор приватне безбедности на просторима СФРЈ поделио је судбину раније државе од оснивања, преко трансформације и престанка постојања. Након сецесије појединих република, приватна безбедност прешла је у надлежност нових држава. У Србији је 1993. године донет пропис о престанку важења норми у области заштите имовине и лица, па је две деценије ова област била нерегулисана. Крајем 2013. године усвојени су Закон о приватном обезбеђењу и Закон о детективској делатности, а потом подзаконски акти за примену. Област приватне безбедности регулисана је матичним прописима, док акти предвиђају програме обуке, едукацију кадрова и потребне услове за рад. Посебан је значај норми због апликације РС за пријем у ЕУ и хар монизације са прописима Уније.
\end{abstract}

Кључне речи: безбедност, приватна безбедност, легислатива, едукација, РС и ЕУ .

\section{PRIVATE SECURITY IN SERBIA - LEGAL BASIS AND EDUCATION MEMBERS}

\begin{abstract}
The private security sectorin the former Yugoslavia has shared the fate of the earlier common state starting from inception, through the transformation and to the cessation of existence. After the secession of some Yugoslav republics private security, as well as other areas, were under the jurisdiction of the newly created state. In the Republic of Serbia in 1993 a regulation on the termination of the earlier norms in the field of protection of property, persons and businesses was adopted, after which this area was not legally regulated for two decades. In late 2013, they adopted the Law on Private Security and on the detective business, and then successively some of the by -laws for their application. So the first time after so long, the private security sector had regulated stem regulations, while the actspredict programs and ways of implementation of the training, the training of personnel and the necessary conditions for work. The special significance of this standard is found in the process of application of the Republic of Serbia to join the EU and the harmonization of standards with the EU regulations.
\end{abstract}

Key words: $\quad$ security, private security, legislation, education, RS and the EU. 


\section{УВОДНА РАЗМАТРАҢА}

На почетку трећег миленијума свет карактеришу процеси научног, техничко-технолошког напретка, индустријализације, урбанизације и глобализације. У развијеним земљама остварен је развој духовне културе, материјални непредак и други вредни резултати. Земље у транзицији покушавају да достигну стандарде развијеног света, на материјалном плану и у осталим областима живота и рада.

Након економске кризе 2011-2012. године, поново је покренут точак економије. Велики допринос процесу дале су развијене државе, земље у транзицији и нове светске економске силе (Кина, Русија). Транзицију у посткомунистичким државама пратили су пораст криминала и правна несигурност. Пораст најтежих облика криминала уздрмао је темеље међународне заједнице и запретио да уништи тековине људске цивилизације, посебно након терористичких напада у САД (2001). Постоји и велика опасност од пожара, експлозија, незгода и других ванредних ситуаиија у амбијенту „прљавих” технологија, опасних материја и услед ратних сукоба.

Државе и међународна заједница су у трагању за одговором на криминалне и друге претње, па су системи националне и међународне безбедности у сталном развоју. Безбедност човека и заједнице није изоловано питање државе, региона или организације, већ универзални проблем који захтева мултиагенцијски приступ, унутрашњи и међународни, нормативни и оперативни одговор. Савремена доктрина и пракса сматрају да јединствени национални систем безбедности чине државни и приватни сектор безбедности (Никач, 2013, 11-15). У развијеним државама приватни сектор безбедности развијенији је и компатибилан друштвено-политичком, економском и безбедносном систему. Нешто другачија ситуација је у бившим социјалистичким земљама у просецу транзиције и другим неразвијеним државама.

Приватни сектор безбедности комплементаран је државном, значајно је растеретио полицију и преузео мање сложене безбедносне послове. Сектор ПБ је подсистем система безбедности и обухвата више области, као што су: физичка, техничка, противпожарна и противдиверзиона заштита, заштита на раду (Никач и др., 2013, 28-30). У државама ЕУ приватни сектор безбедности је популаран и његов положај, статус и друга питања уређени су посебним нормама. На нивоу СЕ и ЕУ донето је више нормативних решења која су стандард у овој области, посебно у погледу хармонизације норми и јединствене праксе. Легислатива је од изузетне важности за законито обављање послова, преппоставка успешне организације и пословања на тржишту.

На простору бивше СФРЈ, ова област једно време била је релативно добро регулисана. Након распада, бивше републике постале су 
независне државе, па су нови субјекти преузели права и обавезе. Већина нових држава усвојила је посебне законе о приватном обезбеђењу и детективским пословима.

Србија је била последња која је у овој области, по угледу на земље региона и ЕУ, донела нове прописе (Закон о приватном обезбеђењу и Закон о детективској делатности 2013). Потом је усвојено више подзаконских аката за примену закона, и то: Правилник о програмима и начину спровођења обуке за вршење послова приватног обезбеђења (2014), Правилник о ближим условима које морају да испуне правна и физичка лица за спровођење стручне обуке за вршење послова приватног обезбеђења (2014) и Правилник о боји и саставним деловима униформе службеника обезбеђења (2015). У току је доношење осталих подзаконских аката који су у процедури разматрања пред надлежним органима.

Образовање, обука и усавршавање припадника ПБ значајно је питање јер је сектор део система националне безбедности, који треба да обавља послове на професионалан и законит начин. Изузетно је важно да припадници ПБ имају адекватно образовање, стално усавршавање и обуку, на добробит заједнице и грађана. Подзаконским актима предвиђени су планови и програми усавршавања, неопходни ниво кадрова и професионални стандарди по међународним правилима.

\section{ОСВРТ НА ПРИВАТНУ БЕЗБЕДНОСТ У НЕКАДАШЬОЈ СФРЈ}

Приватна безбедност као категорија није формалноправно постојала у некадашњој Југославији. Као појам егзистирала је безбедносна заштита имовине, лица и пословања. У складу са друштвенополитичким системом и економским приликама, постојао је сектор безбедносне заштите имовине и лица, у пракси познат као сектор ФТО (физичко-техничка заштита).

Након Другог светског рата, створена је ФНРЈ (СФРЈ), у коју су ушле територије бивше Краљевине и успостављене федералне јединице. Правни поредак био је одраз времена у којем је држава створена и настао политички систем, са примесама револуционарног и идеолошким предзнаком. ФНРЈ је била једнопартијска држава социјалистичког политичког и економског уређења, што је значајно за схватање позиције приватне безбедности. Правна, политичка и друга решења била су под овим „кишобраном”, док је у економском смислу земља прошла пут од државне привреде, преко самоуправљања, па до региона у транзицији у којем се развија капиталистички систем, у измењеним условима. Међутим, живот и рад у заједничкој држави прекинут је услед грађанског рата и дошло је до распада заједничке државе. То се одразило и на сектор приватне безбедности, који је поделио судбину заједнице у целини. 
У складу са историјским развојем, СФРЈ је и периодизација у развоју ФТО и пословима обезбеђења имовине, лица и пословања. У почетку је била строга правна регулатива, затим следи фаза релативне уређености и, на крају, период укидања прописа и одсуства норми. У последњој фази СФРЈ (РС), пре ратног сукоба, многа предузећа остала су без заштите имовине и пословања (Бошковић М., Кековић 3., 2000, 14-18).

a) Закон о народној милицији (1946) обележио је прву фазу у развоју обезбеђења имовине и лица. Народна милиција била је конципирана као извршни орган управе надлежан за очување јавног реда и мира, заштиту имовине, безбедност грађана и помоћ другим органима за поштовање поретка. У индустријским предузећима, заводима и установама била је образована Индустријско-заводска народна милиција, претеча сектора обезбеђења имовине и лица (ФТО, сектор ПБ). Задаци ИЗНМ били су: обезбеђење објеката, надзор над сумњивим лицима, спречавање саботажа и диверзија, контрола примене прописа у делу JPM, контрола околине објеката, хватање и пријављивање починилаца кривичних дела против имовине и предузећа, контрола противпожарне заштите и др. (Закон о народној милииији, 1946). Према члану 14, припадници ИЗНМ имали су значајна овлашћења, већа него данас редовни састав полиције. То је донекле разумљиво ако се има у виду временски и друштвени контекст у којем је закон донет, посебно амбијент у којем се примењивао.

Закон о органима унутрашњих послова (1951) заменио је претходни и по њему је престала са радом ИЗНМ, па је услед тога настао правни вакуум у погледу овлашћења за рад служби обезбеђења. Према закону, њени задаци прешли су у надлежност редовних органа, док је употреба ватреног оружја третирана као изузетак (нпр., одбијање напада на штићени објекат или имовину веће вредности).

Правилник о служби обезбеђења имовине, привредних организаиија и установа (1963) био је важан подзаконски акт који је донео државни секретаријат за унутрашње послове. Смисао акта је унификација система безбедносне заштите објеката и уједначавање поступања у пракси. Правилник је предвиђао надлежност, права, дужности и начела организације службе обезбеђења, док су надзор и иницијатива за увођење службе заштите били у надлежности органа унутрашњих послова.

б) Наредна фаза у развоју почиње 1967. године, када су у области унутрашњих послова промењени прописи на свим нивоима и органи безбедности сведени на општинске секретаријате под утицајем локалних органа. Промене су уследиле након IV Пленума СКJ и смене тадашњег министра унутрашњих послова са сарадницима, након оптужби за наводне злоупотребе у служби безбедности. То се одразило на безбедносну заштиту имовине и лица која су прешла у 
надлежност предузећа, док су службе заштите лица, имовине и пословања изузете из надлежности органа унутрашњих послова. Редовној полицији ограничен је улазак у круг предузећа, осим по позиву и услед пожара, хаварија и већих несрећа.

в) Закон о основама друштвене самозаште (1973) најважнији је пропис у овој фази и важио је до 1986. године. У то време била је доминантна друштвена својина и целокупан систем био је конципиран на њеној заштити. Предузећа су морала да организују службу заштите, док су друге организације и заједнице морале да имају физичко и техничко обезбеђење објеката. У периоду од 1973. до 1990. године у правни поредак уведен је концепт тзв. друштвене самозаштите (Никач, 2012, 50-51).

Одредбама закона подробније су дефинисани самозаштита (чл. 10), овлашћења служби обезбеђења, надлежност и обука (чл. 1114) и друга питања, као што су казне за неизвршавање предвиђених обавеза (Закон о основама друштвене самозаштите, 1973).

Закон о систему друштвене самозаштите донет је 1986. године, након чега је престао да важи претходни. Предвиђено је да се у спровођењу мера ФТО могу користити услуге организација регистрованих за ове послове, док две организације или више њих могу заједнички организовати послове обезбеђења и заштите. Проширена су нека овлашћења ФТО, као, на пример, утврђивање идентитета лица и друга (Закон о систему друштвене самозаштите, 1986). Доношење прописа о начину употребе ватреног оружја радника непосредног физичког обезбеђења пренето је на тадашњи РСУП (Бошковић М., Кековић 3., 2000, 36).

Закон о престанку важења одређених закон а и других прописа (1993) ставио је ван снаге Закон о систему ДСЗ и још неке прописе, па је Србија била без закона у овој области две деценије. То је проузроковало проблеме у обављању послова ФТО, произвело правну несигурност и створило проблеме у раду предузећа. Посебан проблем била је примена овлашћења у пословима ФТО, па су примењиване сродне правне норме и попуњаване правне празнине. Веома је био изражен проблем ношења и коришћења ватреног оружја припадника ФТО приликом обезбеђења виталних објеката, обезбеђења банака, транспорта новца и других послова.

\section{ПРИВАТНА БЕЗБЕДНОСТ У СРБИЈИ ДО УСВАЈАҢА НОВИХ ПРОПИСА}

После престанка важења прописа у области ФТО и почетка рата у СФРЈ, настао је правни интерегнум у овој области. На стање у свим областима утицала је ситуација у друштву и последице трагичног рата, економска нестабилност и санкције уведене против СРЈ. 
То је имало утицаја на сектор ФТО и пружање услуга, који је морао да се прилагоди новим околностима и припреми за трансформацију.

До усвајања нових прописа, Србија је била једина земља у региону која није правно уредила ову област. У овом периоду примењиване су комплементарне норме из других области и „споредно” законодавство. Сектор приватне безбедности био је регулисан одредбама неколико закона, у зависности од области рада и конкретних питања.

Оснивање, регистрација, статусне промене и друга питања у вези са предузећима за обезбеђење били су предвиђени прописима о привредном пословању (Закон о предузећима). Због недостатка законске регулативе ФТО, ово решење било је изнуђено, што није добро јер су у питању специфични субјекти према области рада, средствима (ватрено оружје, принуда) и другим елементима (Петровић, 2008, 72-75). Службе ФТО пружале су класичне безбедносне услуге, као што су: обезбеђење имовине, транспорта новца и вредности (статичко и мобилно), обезбеђење лица и важних личности (ВИП), приватне детективске истраге, проналажења несталих лица или имовине.

У периоду од 1993. до 2013. године, примењиване су одредбе других прописа, национални стандарди у области приватног обезбеђења, интерни општи и појединачни прописи. Након 2000. године и почетка друштвених промена, било је више законодавних иницијатива и предлога закона о приватној безбедности и детективској делатности.

a) Релевантне законске одредбе односиле су се на област рада сектора ФТО и у том смислу издвајамо Закон о оружју и муницији (1992-2011), Закон о спречавању насиьа и недоличног понашања на спортским приредбама (2003-2009), Закон о окупљању грађана (1992-2001) и др. Истим прописима била су заштићена људска права, грађанске слободе и универзалне вредности. Велики значај имале су норме које предвиђају Закон о класификаичји делатности (2009) и Уредба о класификаиији делатности (2010).

Закон о оружју и мунииији важио је донедавно, када је донет нови законски текст у овој области. У недостатку матичних извора, ЗООМ је значајно коришћен и оправдао је место и улогу у правном поретку, јер је често био једини правни извор у борби против насиља и заштити универзалних вредности. Одредбама закона регулисана су важна питања као што су обављање послова безбедности са оружјем, набавка, држање и ношење оружја, обука и др. Народна скупштина усвојила је нови Закон о оружју и мунищији, којим су пооштрени услови за добијање дозволе за држање и ношење ватреног оружја (2015). 
Закон о спречавању насиља и недоличног понамања на спортским приредбама (тзв. Anti-hooligans Act) има за циљ да се у борбу против насиља у спорту укључи што већи број субјеката (Никач Ж., Милошевић Г., 2011, 31-37). Најпозванији су спортски клубови и удружења, државни органи (полиција, суд, JT, министарства), заједница, владине и невладине организације. Законодавац је покушао да истакне одговорност спортских клубова, савеза и организатора који имају највећу добит од ових манифестација. Поред осталог, од великог значаја је увођење редарске службе и већа овлашћења редара. У одредбама је евидентна аналогија са страним решењима и праксом, али и поред тога пропис је мењан више пута, што није акт правне сигурности. Смисао закона је да се заједница избори са проблемом хулиганизма на ефикасан начин, као што је то учинила В. Британија и чланице ЕУ.

Закон о класификацији делатности и Уредба о класификаиији делатности нису прописи класичног безбедносног карактера, али су од значаја у номенклатури и класификацији послова. У области приватне безбедности класификоване су три гране и у оквиру сваке следеће групе:

a) Грана 80.1 Делатност приватног обезбеђења - група 80.10; б) Грана 80.2 Услуге система обезбеђења - група 80.20 и в) Грана 80.3 Ис тражне делатности - група 80.30 .

б) Национални стандарди у области приватног обезбеђења утврђени су одлукама Института за стандардизацију Србије. Као овлашћено национално тело за стандардизацију, поред преношења или проглашавања међународних стандарда, ИСС израђује и доноси националне стандарде у областима у којима за то постоји интерес (Кековић, 2011, 92-97).

У очекивању нормативног уређења ФТО и са циљем повећања квалитета услуга, професионализације и прихватања међународних стандарда, ИСС је усвојио више националних стандарда из области безбедности лица, имовине и пословања: СРПСА.Л2.001:2008, Друштвена безбедност - Услуге приватног обезбеђења - Речник, ${ }^{1}$ СРПСА.Л2.002:2008, Друштвена безбедност - Услуге приватног обезбеђења - Захтеви и упутство за оцењивање усаглашености ${ }^{2}$ и СРПСА.Л2.003:2010, Друштвена безбедност - Процена ризика у заштити лица, имовине и пословања. ${ }^{3}$

Институт за стандардизацију заступа интересе Србије у Међународној организацији за стандардизацију (ISO), у којој наша земља има статус пуноправног члана од 1950 . године.

\footnotetext{
${ }^{1}$ Службени гласник РС, бр. 104/08.

${ }^{2}$ Службени гласник РС, бр. 107/09.

${ }^{3}$ Службени гласник РС, бр. 92/10.
} 
в) Интерни општи и појединачни прописи били су важни у прошлости јер није било законских решења у овој области. Због тих и других разлога, активност привредних субјеката у области ФТО и ППЗ обављала се на основу екстерних и интерних аката (Милошевић M., 2006, 15-17).

Спољашни правни акти су општи правни прописи садржани у правилницима и наредбама надлежних органа, организација и стручних установа, донети у оквиру законских овлашћења.

Унутрашњи правни акти су документи од значаја за обављање послова и задатака ФТО лица, имовине и пословања, и то: статут привредног субјекта, правилник о раду службе ФТО, одлука о пословној тајни, правилник о процедурама службе ФТО, наредбе, радни налози и др. Према неким ауторима, ови акти деле се на опште (упутства, смернице, планови, програми, методологије, пројекције) и појединачне (процедуре, нормативи, радни налози) (Даничић М., Стајић Љ., 2008).

г) Законодавне иницијативе у области приватне безбедности у Србији од 2000. до 2013. године биле су одраз стања у заједници. Друштвене промене покренуле су и питање трансформације целокупног сектора безбедности, па су најпре инициране промене у МУП РС и потом у другим деловима овог сектора. Најпре је некадашњи Ресор државне безбедности издвојен из МУП РС и основана БИА (Закон о БИА, 2002). Потом је Ресор јавне безбедности трансформисан у Дирекцију полиције, у чијем су саставу линије рада и територијалне јединице (Закон о полицији, 2005). Уследила је трансформација војних служби безбедности и оснивање војних безбедносних служби (Закон о ВБА и ВОА, 2009). На крају је формирана Комунална полиција (Закон о комуналној полищији, 2009), која је задужена за одржавање комуналног реда и за друга питања. Недавно је усвојен нови Закон о полицији, који је доста сличан са претходним, али је увео неколико новина које се односе на: место, улогу и задатке МУП-а РС и Дирекције полиције; међународну полицијску сарадњу; полицијска овлашћења, мере и радње; полицијске послове; људске ресурсе, каријерни развој и др. (Лештанин, Никач, 2016).

Кровна институција је Савет за наиионалну безбедност, на чијем је челу председник Републике и у чији састав улазе руководиоци служби, начелник ГШ, министри (унутрашњих послова, правде, одбране), председник Владе, предс едник Скупштине и лица по позиву (Одлука о СНБ, 2007). Савет координира рад служби безбедности на нивоу Републике, разматра питања из ове области, даје предлоге мера за унапређење националне безбедности, побољшање сарадње са државним и органима локалне самоуправе и др. За потребе СНБ основана је Канцеларија Савета за националну безбедност, која обавља административне, техничке и друге послове (Уредба о осниваљу 
Канцеларије СНБ, 2009). Оперативно тело Савета је Биро за координаџију служби безбедности, као механизам координације и сарадње служби из обавештајно-безбедносне заједнице.

Сектор приватне безбедности остао је последњи и његова транформација још није окончана. Пре усвајања нових закона било је више предлога од 2000. до 2013. године, и то хронолошки: а) Начрт закона о физичко-техничком обезбеђивању (предлагач МУП РC, 2002); б) Модел закона о приватној делатности обезбеђења (ЦЦВО, 2006); в) Закон о приватној делатности обезбеђења лица и имовине и детективској делатности (LEX, 2006) и г) Закон о приватној делатности обезбеђењ $а$, самозаштитној и детективској делатности (ПКС, 2007) (Никач Ж., Павловић Г., 2012, 1-10).

\section{НОВИ ПРОПИСИ У ОБЛАСТИ ПРИВАТНЕ БЕЗБЕДНОСТИ У СРБИЈИ}

Република Србија је до скоро била једина земља у региону која није имала правно регулисану област приватне безбедности. Недостатак правне регулативе је оставио негативне последице у погледу безбедности заједнице, утицао на стање и развој сектора приватне безбедности. То се осетило након доласка страних приватних безбедносних компанија на наше тржиште које су скоро истиснуле домаће компаније из ових послова.

Ситуација се променила набоље када је Србија истакла апликацију за пријем у EУ, посебно након попписивања Споразума о стабилизащији и придруживању (СПП). Према члану 77 СПП, наша земља обавезала се на реформу сектора безбедности у процесу „постепеног постизања усклађености са техничким прописима Заједнице, европским стандардима, процедурама за оцењивање усаглашенос ти са захтевима стандарда и прописа" (Закон о потврђиваюу Споразума о СПП између ЕУ и РС, 2008). То је подразумевало и испуњавање обавеза које произлазе из чланства у међународној организацији за приватно обезебеђење - CoESS (Confederation of European Security Services). ${ }^{4}$

a) Први корак било је усвајање Стратегије наиионалне безбедности ${ }^{5}$ као кровног документа према којем је приватни сектор безбедности саставни део система националне безбедности. Потом је успостављена сарадња МУП РС и Удружења за ФТО при Привредној комори Србије (Меморандум о сарадњи МУП РС и ПКС, „Пове-

\footnotetext{
${ }^{4}$ Извор: http://www.coess.org (16. 6. 2016)

${ }^{5}$ Извор: http://www.mod.gov.rs/cir/dokumenta/strategije/usvojene/Strategija nacionalne bezbednosti Republike Srbije.pdf, (16. 6. 2016).
} 
рење у квалитет обезбеђења критичне инфраструктуре”, 2013), ${ }^{6}$ након чега је уследило више заједничких састанака, законских и других предлога. Коначни резултат било је усвајање Закона о приватном обезбеђењу и Закона о детективској делатности (2013), који су донети по проевропском моделу и слично земљама у окружењу. У правно-техничком смислу, усвојена су два одвојена текста закона, а основни разлог је релативно слична, али ипак различита област деловања, која се уређује поменутим прописима.

Даље су донети важнији подзаконски акти: Правилник о ближим условима које морају да испуне правна и физичка лица за спровођене стручне обуке за вршење послова приватног обезбеђења (2014), Правилник о програмима и начину спровођена обуке за вршење послова приватног обезбеђења (2014) и Правилник о боји и саставним деловима униформе службеника обезбеђења (2015). У току је поступак усвајања још неколико подзаконских аката чији су нацрти предати у процедуру оцене сагласности са осталим законима, потом следи правно-техничка редактура и одлука надлежног органа.

Усвајањем нормативних решења створени су почетни услови за сигурнији амбијент за рад сектора приватне безбедности, детектива и детективских агенција, решавање статусно-правних и других питања.

б) Закон о приватном обезбеђењу је дужи текст који садржи 91 члан, укупно 12 одељака и, са становишта правне технике, релативно је складне композиције. У тексту се наводе послови приватног обезбеђења (процена ризика, заштита лица и имовине, одржавање реда на јавним скуповима, системи техничке заштите, обезбеђење транспорта новца и др.), док, сходно члану 7, нису дозвољени послови посредовања и наплате потраживања („рекетирање”). Даље се наводе важнија поглавља која обухватају: лиценце (области), начин вршења послова приватног обезбеђења (физичка и техничка заштита, транспорт новца, редари, контролни центар, самозаштита), овлашћења (провера идентитета, преглед лица и предмета, упозорење и наређење, привремено задржавање, употреба средстава принуде - везивање, физичка снага, ватрено оружје, употреба дресираних паса), означавање и представљање, евиденције, заштита података, надзор, казнене, прелазне и завршне одредбе (Миланковић-Васовић, 2014).

У погледу лицеенции (чл. 8-18), усвојени су међународни стандарди према којима се систем лиценци заснива на типовима услуга безбедности које субјект приватне безбедности (не) сме да пружа и утврђен временски оквир (5 година) у функцији професионализације. Предвиђени су надзор субјеката приватне безбедности, казнени систем (новчане казне) и поништење лиценци у случају кршења закона.

\footnotetext{
${ }^{6}$ Извор: Официјелни сајт ПКС, http :/www.pks.rs (16. 6. 2016)
} 
Даље се наводе општи услови које мора да испуњава физичко лице за добијање лиценце за обављање послова приватног обезбеђења (држављанство, усраст, школска спрема, безбедносна провера, психофизичка способност, обука за ватрено оружје и за приватно обезбеђења, стручни испит). Дилема постоји око минимума ССС јер има мишљења да не треба условљавати право на рад, посебно имајући у виду да „потребна знања и обуку физичко лице може добити кроз предвиђене програме обуке, без обзира на ниво стручне спреме" (Анализа ЦЕАС, 2013, 29-30). Примедба је, с једне стране, оправдана jep за одређени број послова, као нпр. за физичку заштиту лица и имовине, редарску службу на јавним скуповима и спортским приредбама - није потребан средњи ниво школске спреме. С друге стране, законодавац је у сарадњи са ПКС покушао да подигне критеријуме, и то управо у функцији квалитета послова.

Полагање стручног испита за добијање лиценце у МУП-у РС добро је решење јер се ови послови и на тај начин уздижу у погледу квалификације, квалитета услуга и др. Важан услов је радно искуство на безбедносним пословима најмање три године, па с тим у вези ослобођење дела обуке за поједине категорије лица. У примени одредбе треба бити опрезан јер постоји опасност од сукоба интереса, нелојалне конкуренције бивших припадника безбедносних служби и повреде равноправности осталих кандидата.

Начин вршења послова предвиђен је у смислу да се не омета рад државних (безбедносних, полицијских и др.) органа, нити да се нарушава спокојство грађана (чл. 19-20). У том контексту, даље се наводе следеће врсте послова: физичка заштита, обезбеђење са оружјем, техничка заштита, планирање, пројектовање, технички надзор, монтаже и одржавања система техничке заштите, обезбеђење транспорта новца, вредносних и других пошиљки, редарска служба, контролни центар и самозаштитна делатност (чл. 21-45).

Уговор између странака је основ за заснивање и вршење послова приватног обезбеђења, што је даље регулисано одредбама $3 a$ кона о приватном обезбеђењу. Закон прецизира да је у питању писани уговор, поједине елементе и дужност извршиоца да о уговору (закључење, промене, раскид) обавести месно надлежну полицијску управу. Смисао обавештења је у надзору и контроли рада од стране МУП-а РС и посебно територијално надлежне полиције.

Овлашћеља припадника приватног обезбеђења (чл. 46-57) предвиђена су на идентичан начин као и у законима земаља у окружењу. Предвићена су следећа овлашћења: провера идентитета, преглед лица и предмета, упозорење и наређења, привремено задржавање, средства за везивање, физичка снага, посебно дресирани пси, ватрено оружје, обавезно обавештавање, извештавање и оцена оправданости и правилности употребе средстава принуде. Ближи начин 
употребе средстава принуде одређује посебним актом министар (чл. 57), што је оправдано због осетљивости овог питања, а посебно имајући у виду полицијску и судску праксу. Следе стандарди и принципи у примени овлашћења, посебно у односу на средства принуде, као што су градација, сразмерност, законити циљ, поштовање личности и људских права и др.

Надзор и контролу у примени закона врши МУП РС (чл. $70-$ 75). Посебно се проверавају начин чувања и ношења ватреног оружja, психо-физичка способност и оспособљеност радника обезбеђења за руковање оружјем и друге контролне радње.

Стручни савет за унапређење приватног обезбеђења и јавно приватног партнерства у сектору безбедности посебан је орган који је предвиђен са циљем продубљивања сарадње Удружења ПКС за послове приватног обезбеђења и МУП-а РС.

в) Закон о детективској делатности доста је краћи (41 члан), има шест одељака и композицијски је релативно језгровит. У уводним одредбама (чл. 1-3) наводе се област рада, неспојивост детективских послова са пословима државних органа (полиција, безбедносне агенције) и други појмови.

Даље се разрађују услови за обављање детективске делатности који су сродни онима из претходног закона. Разлике постоје у погледу специфичне области рада детектива, школске спреме детектива (BCC) и још по неким посебним елементима (чл. 4-9).

Овлашћења и начин вршења послова детектива (чл. 10-21) комплементарни су природи и врсти ових послова, па се наводе обрада података, уговорни односи, легитимација, ватрено оружје, начин прикупљања и обраде података. Најважнији део односи се на личне и друге податке који могу бити предмет рада детектива, који се прикупљају по начелу сагласности лица. У осталим случајевима, детектив мора да образложи тзв. оправдани интерес, а посебно када се обраћа надлежним органима са захтевом за доставу личних података.

Надзор, евиденције и заштита података (чл. 22-32) битан су део законског текста и претпостављају поступање по начелу bona fides. Документа и подаци чувају се у сефовима и обезбеђеним местима, а детективи су дужни да чувају као службену тајну све податке и не смеју их злоупотребити. На крају следе казнене (чл. 3336), прелазне и завршне одредбе (чл. 37-41).

Усвојена решења из овог закона идентична су онима које су донеле бивше југословенске републике, земље из ширег окружења и државе чланице ЕУ по сродном моделу. 


\section{ПОДЗАКОНСКИ АКТИ И ЕДУКАЦИЈА ПРИПАДНИКА ПРИВАТНЕ БЕЗБЕДНОСТИ}

Требало је да подзаконски акти за примену закона буду донети у кратком року од шест месеци од њиховог усвајања, односно до половине 2014. године. Међутим, због познате ситуације у овој области и бирократске праксе, акти нису усвојени на време, па је примена закона каснила. Након тога, Управа полиције МУП-а РС у сарадњи са Удружењем за приватну безбедност ПКС покренула је поступак доношења потребних аката, па је до сада усвојено укупно једанаест подзаконских аката, од чега седам за приватно обезбеђење и четири за детективску делатност. У погледу процеса усавршавања, усвојени су подзаконски акти који регулишу: а) програм и начин спровођења обуке за послове приватног обезбеђења; б) ближе услове које морају да испуне правна и физичка лица која спроводе стручну обуку за вршење послова приватног обезбеђења и в) програм обуке и оспособљавања лица за вршење детективских послова, начину спровођења обуке и оспособљавања и полагања стручног испита за детектива.

- Правилник о програмима и начину спровођења обуке за вршење послова приватног обезбеђења први је у низу аката који је усвојен и објављен у официјелном гласнику (2014). Правно-технички, без обзира на велики наслов, у питању је један релативно добар и концизан подзаконски акт који ума укупно 10 чланова, са 5 прилога.

Правилник предвиђа да се стручна обука спроводи за послове процене ризика, физичко-техничку заштиту лица и имовине, као и одржавање реда, системе техничке заштите (планирање, пројектовање и надзор) и монтажу, пуштање у рад и одржавање ових система (чл. 2). То је сагласно одредбама закона које се односе на области рада приватног обезбеђења и сходно томе је планирана обука по облас тима.

Предвиђају се наставни облиии као што су предавања, вежбе, курсеви, радионице и други, уз одређени фонд часова и напомену да су дела обуке ослобођени кандидати са положеним испитом из ППЗ (чл. 3). Провера знаға је у форми писаног завршног теста (25 питања), где се вреднује и присутност настави. Оцене су описне (положио, квалитетан, истиче се), док се тест може полагати највише три пута, након чега следи поновна обука (чл. 5-6).

Важан елемент усавршавања је кондищиона обука, која је значајна за успешно обављање већине послова приватног обезбеђења (чл. 7). Обука обухвата вежбе физичке снаге и примене средстава принуде, затим обуку за посебно дресиране псе (водичи) и за вежбовно гађање. Значај овог дела обуке не треба додатно објашњавати jep су познате штетне последице незаконите употребе средстава принуде. Стога је повећана одговорност руководилаца у сектору при- 
ватне безбедности, тренера и припадника. Уговором о спровођењу обуке разрађена су поједина питања која се односе на права и обавезе полазника, даваоца услуга и др. (чл. 9).

У прилогу акта (бр. 1-5) налазе се Програми стручне обуке за поједине области и сертификат (потврда) о стручној обучености. У програмима се третирају методске јединице према областима и сматрамо да су замишљени доста амбициозно, па остаје да се види примена у пракси. Верујемо да ће после протока времена и почетних искустава из предстојећег наставног циклуса поједини делови програма бити иновирани и прилагођени захтевима полазника и компанија.

Највећи изазов у примени јесте да се успостави квалитет стручне обуке и поставе професионални стандарди, јер од тога зависи будућност сектора приватне безбедности и поверење корисника. Због финансијске ситуације, проблем може бити намера приватних фирми да спроведу интерну обуку кадрова (Милетић, 2014), а да при томе немају капацитете.

- Правилник о ближим условима које морају да испуне правна и физичка лииа за спровођење стручне обуке (2015) јесте акт који такође има дугачак наслов, али је по нашем мишљењу правно-технички релативно добар и концизан (5 чланова, 2 прилога-обрасца) и у великој мери наслања се на претходни.

Правилником се прописују ближи услови у погледу просторија, материјално-техничких средстава и опреме и стручне оспособљености лица која спроводе стручну обуку, а које треба да испуни правно или физичко лице за добијање одобрења МУП-а РС.

У члану 2 детаљније су предвиђени услови које треба да испуне лица за поједине врсте обука и, сходно томе, добију овлашћење за обављање послова, и то:

а) овлашћење „О1” - процена ризика у заштити лица, имовине и пословања у области приватног обезбеђења;

б) овлашћење „О2” - физичко-техничка заштита лица и имовине и одржавање реда на спортским приредбама, јавним скуповима и местима окупљања грађана и

в) овлашћење „ОЗ” - планирање, пројектовање и надзор над извођењем система техничке заштите, послови монтаже, пуштања у рад и одржавања система техничке заштите.

Дистинкција је потребна јер се програми едукације разликују за поједине врсте послова, на основу чега су различита и овлашћења. Постоји могућност да физичко или правно лице поседује капацитете за пружање услуга обуке за више области, па је правно-техничко питање да ли ће се донети јединствено решење или појединачни акт за конкретну област.

Захтев се подноси МУП-у РС и правно или физичко лице које жели да врши стручну обуку за обављање једног посла или више вр- 
ста послова приватног обезбеђења подноси потребну документацију (извод из регистра, акт о акредитацији, власнички лист или уговор о закупу или праву коришћења просторија, списак предавача). Присталице смо смањења бирократизације поступка и олакшања спровођења обуке у овој области, јер услужна делатност треба да буде у функцији привредних субјеката и лакшег остварења профита.

Правно и физичко лице које добије овлашћење за спровођење стручне обуке за приватно обезбеђење дужно је да води службене евиденције о предавачима, контролорима и о кандидатима (чл. 4). На тај начин се води рачуна о кредибилитету едукационог центра и предавача, корисника услуга и сектора приватне безбедности у целини.

Третман података је посебан и они се морају користити са изузетном пажњом, као и чувати од свих врста злоупотреба. Предвиђено је да се евиденције о кандидатима и извођачима стручне обуке воде ручно или електронски, у складу са прописима којима се уређује заштита података о личности и да се чувају најмање 10 година (чл. 4, ст. 2). Повереник за информације од јавног значаја и заштиту података о личности указао је на третман података, посебан правни режим и потребу да се заштите права грађана (Закон о слободном приступу ин формачијама од јавног значаја, 2004-2010).

У прилогу акта су типски обрасци пријава за извођаче стручне обуке (бр. 1) и за кандидате (бр. 2).

- Правилник о програму обуке и оспособљавања лииа за вршење детективских послова, начину спровођења обуке и оспособљавања и полагања стручног испита за детектива (2015) јесте акт који има необично велики наслов, али је кохерентан и нема велики број одредаба (18) са прилозима (Програм обуке по методским јединицама).

Обуку, оспособљавање кандидата за детективе и полагање стручног испита спроводи МУП РС (чл. 2). Даље се предвиђају техничка питања спровођења обуке: термини и обавештавање (чл. 4), пријављивање и потребна документација (чл. 5), трајање наставе и др. Обука је осмишљена тако да обухвата предавања и вежбе према утврђеном програму, а изводи се теоретски, практичним радом и на други примерен начин (чл. 6).

Због природе послова за које се спороводи обука, предавачи су лица са ВCС која имају стечено образовање на основним, мастер и специјалистичким академским студијама, специјалистичким струковним студијама, односно на основним студијама у трајању од најмање 4 године или специјалистичким студијама на факултету из области безбедности, правних или економских наука и најмање 5 година радног искуства на пословима безбедности (чл. 7). Опредељење законодавца је оправдано јер су у питању суптилни и веома осетљи- 
ви послови, па је потребан мултидис ициплинарни приступ и обазривост у погледу поштовања људских права и грађанских слобода.

Након завршене обуке полаже се стручни испит пред Комисијом МУП-а РС, уз испуњење стандардних елемената (пријава, документација, таксе). Остале одредбе посвећене су спровођењу полагања стручног испита и односе се на састав и рад комисије, стручне и административне послове, време и место обављања испита, испитне рокове, уверења и др. (чл. 10-17).

Важан део акта чини Програм за обуку и оспособљавање физичких лица за вршење детективских послова и полагање стручног испита за детектива, који се налази у прилогу. Од важнијих области и методских јединица, наводе се: основи детективске делатности, право приватне безбедности, основи кривичног материјалног и процесног права, основи прекршајног материјалног и процесног права, заштита података о личности и тајност података, основи криминалистике (тактика, методика, техника и оператива), основи облигационог права (посебно штета и уговори), основи управног права (општи управни поступак), професионална етика и сродни полицијски, безбедносни и управни послови.

Мишљења смо да су овако конципиран Програм обуке за детективе и високообразовани предавачи важан показатељ озбиљности приступа државе овом питању, посебно зато што је ова област код нас у повоју и потребно је време за прве критичке оцене и предлоге за унапређење.

- Остали подзаконски акти су у фази доношења и један број предлога дат је у даљу процедуру Секретаријату МУП-а РС и републичком органу за законодавство, па се очекује оцена о сагласности предлога са важећим прописима и корекције појединих решења. Након тога, предлози иду на стручну дебату и на крају их усваја надлежни орган, по правилу министар унутрашњих послова.

\section{УМЕСТО ЗАКљУЧКА}

Република Србија је последња од некадашњих југословенских република која је донела прописе у области приватне безбедности Закон о приватном обезбеђењу и Закон о детективској делатности. Разлози за кашњење су бројни, али су најважнији тешка друштвенополитичка ситуација, реликти прошлости и последице минулог рата. Усвајање прописа много значи за правну сигурност уопште и рад у овој области, али и доприноси успостављању професионалних стан дарда и изградњи јединствене праксе.

Због објективних ограничења нисмо могли да детаљније укажемо на међународне правне изворе СЕ и ЕУ у овој области. Поједини међународни документи и одлуке међународних струковних уд- 
ружења $(\mathrm{CoESS})^{7}$ били су значајни за усвајање наших закона и подзаконских аката. Дубљи смисао легислативе је да се створе услови за интеграиију приватне безбедности у систем начионалне безбедности PC. У средишту система је човек и људска потреба за сигурношћу, као један од показатеља квалитета живота и одрживог развоја (Милтојевић, 2006, 430-431). Област приватне безбедности предвиђена је у оквиру Стратегије националне безбедности и на тај начин се стварају услови за потпуно и интегрисано функционисање система.

Закон о приватном обезбеђену и Закон о детективској делатности су полазни оквир за регулацију сектора приватне безбедности, па се очекује да МУП РС у сарадњи са Удружењем за приватну безбедност ПКС у пракси допринесе примени законских решења. У том смислу, значајно је усвајање више подзаконских аката, али се очекује усвајање осталих, што ће помоћи развоју добре праксе.

Обука је важно питање и у том контексту од посебног значаја су акредитација центара за едукацију и обука кадрова по савременим програмима и професионалним стандардима ЕУ. У овом делу ваља бити опрезан јер смо сведоци лоших искустава из прошлости како у реформи редовног образовања тако и осталих облика образовања и едукације. Потребно је одређено време за примену нових прописа и стицање почетних искустава у пракси рада едукационих центара, обуке кадрова и другим повезаним областима. Након тога биће могуће да се дају прве утемељене критичке оцене о резултатима у реформи сектора приватне безбедности, правној регулативи, образовању кадрова и осталим значајним питањима. На основу тога могући су конкретнији предлози за унапређење рада у овој области, побољшање едукације и образовања кадрова, као и законит рад на задовољство заједнице и корисника.

\footnotetext{
7 Šre: http://www.coess.org.

Confederation of European Security Services - CoESS (16.06.2016) је кровна асоцијација националних удружења приватних безбедносних компанија, основана 1989. године на иницијативу више приватних компанија из Европе. Циљ асоцијације је да осигура заштиту интереса националних организација приватне безбедности на међународном плану кроз учешће у раду, путем хармонизације националних прописа и заједничким акцијама чланица. Организација окупља око 40 држава из Европе, од којих су 28 из ЕУ (чланице), док су остале из држава нечланица (нпр., БиХ, РМ, РС, Норвешка, Швајцарска, Турска).
} 


\section{ЛИТЕРАТУРА}

Бошковић, М., Кековић, 3. (2000), Обезбеђење лица, имовине и пословања предузећа, [Security of persons, property and business enterprises], Београд: ВШУП,14-18.

Даничић, М., Стајић, љ. (2008), Приватна безбједност [Private Security], Бања Лука: ВШУП

Лештанин Б., Никач Ж. (2016), Коментар Закона о полицији [Commentary on the Police Law], Београд, Пословни биро

Закон о детективској делатности [Private Detectives Laws], Службени гласник PC бр. 104 (2013)

Закон о слободном приступу информацијама од јавног значаја [The Law on Free Access to Information of Public Importance], Службени гласник РC бр. 120(2004), 54 (2007), 104(2009) и 36 (2010)

Закон о класификацији делатности [The Law on Classification of Business Activities], Службени гласник бр.104 (2009)

Закон о народној милицији [National Police Law], Службени лист ФНРЈ бр. 101 (1946).

Закон о окупљању грађана [Public Assembly Law], Службени гласник PC бр. 51(1992), 53 (1993), 67(1993) и 48 (1994), Сл. лист СРЈ бр. 21(2001) СУC

Закон о органима унутрашњих послова [The Internal Affairs Law], Службени лист ФНРЈ бр. 30(1956)

Закон о оружју и муницији [Arms and Ammunition Law], Службени гласник бр. 9 (1992), 53(1993), 67(1993), 48(1994), 44(1998), 39(2003), 85(2005) - др. закон, 101(2005) - др.закон и 27(2011) - УС, (стари)

Закон о оружју и муницији [Arms and Ammunition Law], Службени гласник бр.20 (2015)

Закон о основама друштвене самозаштите [Social Self-Protection Law], Службени гласник РС бр. 39(1973)

Закон о приватном обезбеђењу (Private Security Law), Службени гласник PC бр. 104(2013)

Закон о престанку важења одређених закона и других прописа [Law on the Abrogation of certain laws and regulations], Службени гласник РС бр. 18(1993)

Закон о систему друштвене самозаштите [Social Self-protection System Law], Службени гласник бр. 14(1986)

Закон о спречавању насиља и недоличног понашања на спортским приредбама [Law on Prevention of Violence and Misbehavior at Sports Events], Службени гласник бр. 67 (2003), 101(2005), 90(2007), 72(2009) - др. закон и 111(2009)

Закон о БИА [Security Information Agency Law], Службени гласник РС бр. 42 (2002) и 111(2009)

Закон о полицији [The Police Law], Службени гласник PC бр. 101 (2005), 63(2009-УС) и 92(2011)

Закон о полицији [The Police Law], Службени гласник PC бр. 06(2016)

Закон о ВОА и ВБА [The Law on Military Intelligence Agency and the Military Security Agency], Службни гласник РС бр. 88 (2009)

Закон о комуналној полицији [The Communal Police Law], Службени гласник PC бр. $51(2009)$

Закон о потврђивању Споразума о стабилизацији и придруживању између европских заједница и држава чланица, са једне стране, и Републике Србије, са друге стране [The Law on the Ratification of the Stabilisation and 
Association Agreement between the European Community and the Member States, on the one hand, and the Republic of Serbia, on the other hand], Службени гласник РС - Међународни уговори, бр. 83 (2008)

Кековић, 3. и др. (2011), Процена ризика у заштити лица, имовине и пословања [Risk assessment in the protection of persons, property and business operations], Београд: Центар за анализу ризика и управљање кризама, 92 97

Миланковић-Васовић Љ., (2014), Приватно обезбеђење и детективске услуге [Private Security and Detective Services], Правни информатор бр. 1, Београд: Интермех.

Милетић, С. (2014), Коментар Правилника о ближим условима које морају да испуне правна и физичка лица за спровођење стручне обуке за вршење послова приватног обезбеђења и Правилника о програмима и начину спровођења обуке за вршење послова приватног обезбеђења [Comments on the Rule book on specific conditions to be met by legal entities and individuals in order to carry out the vocational training of private security personnel, and the Rule book on the programs and processes of implementing the vocational training of private security personnel], („Сл. гласник РС”, бр. 117/2014), Београд: „Параграф”

Милошевић, М. (2006), Физичко-техничко обезбеђење и против-пожарна заштита [Physical-technical Security and Fire Protection], Збирка прописа, Београд: „Глосаријум”, 15-17

Милтојевић, В. (2006), Одрживи развој и квалитет живота [Sustainable Development and Quality of Life]. Tеме, 03(06), 430-431

Меморандум о сарадњи МУП РС и ПКС [M emorandum of Understanding between the MOI RS and the Serbian Chamber of Commerce], Поверење и квалитет у обезбеђењу критичне инфраструктуре, Београд 24. 4. 2013, Београд: официјелни сајт ПКС, http:/www.pks.rs (20.1. 2015)

Никач, Ж. (2013), Приватна безбедност и детективска делатност - нови законски прописи у Републици Србији [The Private Security and Detective Services: new legislative acts in the Republic of Serbia], Београд: „Пословни биро",11-15

Никач, Ж., Корајлић, Н., Јахић, А., Бећировић, М. (2013), Правна регулатива сектора приватне безбедности на просторима некадашње СФРЈ, с освртом на последње промене у Републици Србији [Legal regulation of the Private Security Sector in former Yugoslavia, with reference to recent changes in the Republic of Serbia], Сарајево: Факултет за криминалистику, криминологију и сигурносне студије, „Криминалистичке теме” бр. 3$4 / 13$

Никач, Ж. (2012), Концепт полиције у заједници и почетна искуства у Србији [The Concept of Community Policing and the initial experience in Serbia], Београд: КПА, 50-51

Nikac, Z., Milosevic, G. (2011) „Fight against violence at sporting and public events in Serbia - Legislative solutions and actions of the Police", In: Proceedings, European Union - area of freedom, security and justice, Bucharest: Police Academy „Alexandru Ioan Cuza“, Vol 1, Romania, 31-37

Никач, Ж., Павловић, Г. (2012), Право приватне безбедности [Private Security Legislation], Београд: КПА, 1-10

Одлука о Савету за националну безбедност РC [The Decision of the National Security Council RS], Службени гласник PC бр. 50 (2007)

Правилник о програмима и начину спровођења обуке за вршење послова приватног обезбеђења [Rules on the programs and processes of 
implementing the vocational training of private security personnel], Службени гласник РС, бр. 117 (2014)

Правилник о ближим условима које морају да испуне правна и физичка лица за спровођење стручне обуке за вршење послова приватног обезбеђења [Rules on specific conditions to be met by legal entities and individuals in order to carry out the vocational training of private security personnel], Службени гласник РС бр. 117 (2014)

Правилник о програму обуке и оспособљавања лица за вршење детективских послова, начину спровођења обуке и оспособљавања и полагања стручног испита за детектива [Rules on the vocational training program and professional development of persons to carry out detective work, the program implementation proceedings, and the final professional exam for detectives], Службени гласник РС, бр. 74 (2015)

Правилник о служби обезбеђења имовине, привредних организација и установа [Rules on the Security Service for safeguarding property, economic organizations and institutions], Службени лист ФНРЈ, бр. 5 (1963)

Петровић, П. (2008), Контрола и надзор приватног сектора безбедности [Control and Supervision over the Private Security Sector], Зборник: Приватне безбедносне компаније у Србији - пријатељ или претња?, Београд: Центар за цивилно-војне односе, 72-75.

У корак са приватним сектором безбедности [Keeping up with the Private Security Sector], (2013), Анализа, Центар за евроатланске студије - ЦЕАС, Београд, стр. 29-30.

Уредба о класификацији делатности [Regulation on the Classification of Business Activities], Службени гласник РС бр. 54 (2010)

Уредба о оснивању Канцеларије Савета за националну безбедност [Regulation on the establishment of the National Security Council Office], Службени гласник бр. 12 (2009)

\title{
PRIVATE SECURITY IN SERBIA - LEGAL BASIS AND EDUCATION MEMBERS
}

\author{
Željko Nikač $\check{1}^{1}$ Radovan Radovanović ${ }^{1}$, Vojkan Zorić ${ }^{2}$ \\ ${ }^{1}$ Academy of Criminalistic and Police Studies, Belgrade, Serbia \\ ${ }^{2}$ Faculty of Civil Aviation, Belgrade, Serbia
}

\section{Summary}

The private security sector is a more recent concept in the region and in our police and security practice. In the past, during the FRY and later at the level of the Republic of Serbia, the forerunner of the sector was the service for phy sical and technical security of persons, buildings and partly of business. Service PTS (physical and tehnical security) appeared immediately after World War II and was initially under the jurisdiction of the MOI, and after that there has been a transformation of the police service and therefore the PTS has been moved to the jurisdiction of local authorities.

The dep artment of phy sical and technical security of persons, property and business was relatively well developed in the period of former Yugoslavia and the Republic of Serbia. Despite the fact that he did not have enough strong powers in the former period self-management, the service PTS had a specific role in protecting the common (social) 
property and in this context has cooperated with the authorities of the Interior. The legal framework for its work in time narrowing and on several occasions has changed, first in 1973 when the Law on the Foundations of social self. He then adopted the Law on the system of social self (1986), which replaced the previous one, but the essence was similar and treated the area as a PTS system.

After the dissolution of the Yugoslav federation, the security system as a whole has shared the fate of the former state, and the former socialist republics, as newly independent states, accepted full responsibility in the field of national security. Such was the case with the private security sector, however, and it remained legally unregulated in Serbia for two decades, from 1993 to 2013. In the Republic of Serbia in 1993 the Law on the termination of certain laws was adopted, under which the importance of the Act on grounds of social self and several related regulations in the field of PTS ceased. All this resulted in a very negative way in the private security sector, which remained unfinished and in a legal vacuum, in which way it is much more difficult for the PTS sector (private security) to act in the area of the protection of property, persons and businesses. Until recently, the private security industry had no identification law and bylaws but it used complementary legal norms from other applicable laws and regulations.

At the end of 2013 the Republic of Serbia adopted the Law on Private Security Act and the Detective activities, as parent laws of the private security sector. Legal and technical adopted two legal texts and the private security sector initially was divided into a part which refers to the private security of property, persons and businesses, and in this respect the physical and technical security. Another regulation refers to the detective activity whose contours of skills criminal activity, but with a different character and lesser scope and powers according to the areas of work in which it operates.

In the previous part of the data systematic of these two umbrella legislations in the field of private security, and critical review of certain legal institutions, mechanisms and solutions adopted. For the implementation of these laws provides for the adoption and application of some specific secondary legislation in the field of private security.

In the past the initial acts in this area were adopted, related to the program and the implementation of training to perform the duties of private security, as well as details on the conditions that must be met by legal and natural persons for the implementation of vocational training and training program and training of persons to carry out detective work, and how to implement the training and qualification and examination for a detective. The adoption of other necessary by-laws for the law's implementation in the field of private security is ongoing.

Education and training of staff for the private security sector is also an important issue, for the overall system of national security. The question is even more topical regarding our application for membership in the EU and, in this regard, as well as the application of professional standards in this area, respect and protection of human rights and pursuing civil liberties in our community. 